\title{
Monitoring and Management of the Pine Processionary Moth in the North-Western Italian Alps
}

\author{
Chiara Ferracini ${ }^{1, *}$ (C) , Valerio Saitta ${ }^{1}$, Cristina Pogolotti ${ }^{1}$, Ivan Rollet ${ }^{2}$, Flavio Vertui ${ }^{3}$ \\ and Luca Dovigo ${ }^{2}$ \\ 1 Department of Agricultural, Forest and Food Sciences (DISAFA), University of Torino, \\ Largo Paolo Braccini 2, 10095 Grugliasco, Italy; valerio.saitta@unito.it (V.S.); cristina.pogolotti@unito.it (C.P.) \\ 2 Assessorat de l'Environnement, des Ressources Naturelles et du Corps Forestier, Département des \\ Ressources Naturelles et du Corps Forestier, Corps Forestier de la Vallée d'Aoste, \\ Loc. La Grande Charrière, 14, 11020 Saint-Christophe (AO), Italy; i.rollet@regione.vda.it (I.R.); \\ l.dovigo@regione.vda.it (L.D.) \\ 3 Région Autonome Vallée d'Aoste, Assessorat de l'Environnement, des Ressources Naturelles et du Corps \\ Forestier, Département des Ressources Naturelles et du Corps Forestier, Loc. Amerique 127/A, \\ 11020 Quart (AO), Italy; f.vertui@regione.vda.it \\ * Correspondence: chiara.ferracini@unito.it
}

Received: 3 November 2020; Accepted: 24 November 2020; Published: 26 November 2020

\begin{abstract}
The pine processionary moth (PPM), Thaumetopoea pityocampa (Denis and Schiffermüller, 1775) (Lepidoptera, Notodontidae), is considered one of the main insect defoliators of conifers in Southern Europe and North Africa. The species is oligophagous on pines and cedars in Mediterranean countries. This 6-year investigation (2014-2019), carried out in Aosta Valley (NW Italy), on Pinus sylvestris L. aimed to: (i) Monitor the PPM population with pheromone-baited funnel traps; (ii) assess the infestation index (0-5 classes) according to the degree of defoliation; and (iii) apply control strategies, namely Bacillus thuringiensis var. kurstaki (Btk) and mating disruption (MD). In total, 9618 ha were visually monitored and assigned an infestation index. The percentage of woodland stands that were strongly defoliated by PPM (infestation index $\geq 3$ ) increased progressively between 2015 and 2016, affecting from $8 \%$ to $19 \%$ of the total area monitored; this area decreased to $16 \%$ and 13\% in 2017 and 2018, respectively, followed by an abrupt decline to $4 \%$ in 2019. Both Btk applications and mating disruption significantly reduced the infestation. Where $B t k$ was applied, the rate of larval mortality ranged from $79.47 \%$ to $98.43 \%$; conversely, in the control plots, the larval mortality was, on average, $1.56 \%$. The mean number of PPM males captured in traps was significantly lower in the plots where MD was performed, ranging from $8.36 \pm 2.37$ to $13.47 \pm 4.68$. The mean number of males captured in the control plots was, on average, $119.16 \pm 12.68$. The total number of nests recorded per tree was significantly lower in MD plots, ranging from $0.41 \pm 0.05$ to $0.94 \pm 0.14$. In the control plots, there were, on average, $4.37 \pm 0.76$ nests per tree. As already documented for several defoliating forestry insect pests, both Btk and mating disruption proved effective in controlling PPM infestations, and thus, microbial insecticides should be strongly encouraged and adopted by forest managers.
\end{abstract}

Keywords: Thaumetopoea pityocampa; seasonal flight activity; sexual pheromone traps; Pinus sylvestris; forest insect pest; population suppression

\section{Introduction}

The pine processionary moth, Thaumetopoea pityocampa (Denis and Schiffermüller, 1775) (Lepidoptera, Notodontidae) (hereafter referred to as PPM), is one of the most economically important pine defoliators. It is a very ravenous species and is the major phytophagous insect pest in Mediterranean 
forests, being distributed in the Mediterranean Basin in southern Europe, the Balkan area, and North Africa [1,2]. The moth's geographic range is constrained by its requirements for sunshine in winter and its susceptibility to both cold winter and high summer temperatures, and large differences in adult flight period may occur depending on the geographical area. In the last 30 years, the PPM has shifted its altitudinal range by about $110-230 \mathrm{~m}$ in the Alps [3]. Changes in the distribution of the pest have been recorded, with its range greatly influenced by winter air temperature and annual solar radiation [4]. The PPM caterpillar is herbivorous and is a very severe defoliator, causing significant pine tree health decline [5]. The moth is typically found in the pine forests of the Mediterranean area, but the urban environment is also a suitable habitat. Larvae feed on a wide range of Pinus species, especially Pinus nigra Arnold and P. sylvestris L., but other conifers, such as cedars and even Douglas fir, may also be threatened. A severe reduction in photosynthetic area, annual radial growth, biomass, and major economic losses are the main consequences of infestations in pine plantations [6-10]. Young plantations can be severely compromised by massive attacks [11], thus creating favorable conditions for fungi and/or secondary insect pests, such as scolytids and weevils $[10,11]$. Furthermore, larvae from the 3rd instar onwards possess urticating hairs that can have a serious social impact, and associated health problems in humans and domestic or farm animals in urban and suburban areas have been reported [12-14].

The PPM exhibits periodic outbreaks, with a roughly 6-year periodicity in several southern European countries. The cycle, however, is not regular and may vary from 3 to 10 years [15]. Traditional control methods to tackle the PPM include the physical removal of winter nests, ballistic methods (shooting nests from the ground), trunk injection with insecticides, bioinsecticide (e.g., Bacillus thuringiensis Berliner var. kurstaki) [4,16,17], and the use of trunk barriers/traps [12,18]. Understanding the impact of the PPM and precisely when adults will emerge is essential for developing appropriate control strategies. To this end, the sexual female pheromone, (Z)-13-hexadecen-11-ynyl acetate, was identified and extracted by Guerrero (1981) [19], and is used in pheromone-baited traps to monitor male flight activity [20] or for mass trapping [4].

In the present paper, a 6-year study (2014-2019) was carried out to investigate the PPM population density on P. sylvestris in Aosta Valley (NW Italy) using pheromone-baited traps. Given the lack of data for this area in the literature, the aim was to assess the seasonal flight activity of the PPM, recording male adults, and to determine the infestation index according to the degree of defoliation. Moreover, field studies evaluated the effectiveness of control strategies by comparing treated and untreated areas. The control strategies applied were (i) microbial treatments using commercially available B. thuringiensis var. kurstaki, and (ii) mating disruption.

\section{Materials and Methods}

\subsection{Study Area}

Aosta Valley is a mountainous autonomous region located in the north-western part of Italy. It has a total surface area of about $3262 \mathrm{~km}^{2}, 1080 \mathrm{~km}^{2}$ of which is covered by forests. The territory is mainly mountainous, and the average altitude is $2100 \mathrm{~m}$, ranging from about $295 \mathrm{~m}$ to $4810 \mathrm{~m}$ a.s.l. The main valley axis is prevalently west-east oriented, presenting a semi-continental climate.

The tree vegetation consists of Larix decidua Miller, Picea abies L. Karst, mixed stands of Scots pine (P. sylvestris), Mountain pine (P. uncinata Ram.), and Austrian black pine (P. nigra), and Quercus pubescens Will., with the sporadic presence of Populus tremula L. and Betula pendula Roth.

\subsection{Seasonal Flight Activity}

Over a 5-year period (2015-2019), the PPM population was monitored by highly skilled and trained forestry technicians from the "Corpo Forestale della Valle d'Aosta" (CFVDA). Surveys were carried out in four (2015), and 42 municipalities (2016-2019) of the Aosta Valley, and all details are given in Supplementary Materials Table S1. 
Monitoring was performed on the PPM's host, P. sylvestris, and commercially available funnel traps were used at the sampling sites. All trap devices (Super Green, Serbios s.r.l., Badia Polesine (RO), Italy) were baited with dispensers containing the sex pheromone component (Z)-13-hexadecen-11-ynyl acetate (loading rate: $1 \mathrm{mg}$ per dispenser), and placed randomly on trunks and branches of $P$. sylvestris stands at an average height of $2 \mathrm{~m}$. Six traps were placed per hectare. All traps were installed during early June and inspected for adult males at weekly intervals until mid-September to detect the flight period of the target species in the study area. Captured males were counted and removed from the traps. Devices were rotated clockwise to minimize the influence of the individual trapping location. The lure in each trap was replaced every six weeks. The first pheromone trap-check date was the date on which the first captures were recorded.

\subsection{Infestation Index}

The infestation index was recorded in 42 municipalities over a 6-year period (2014-2019) during the winter season (December-February). A 1-ha plot was selected in each municipality. All the plots were characterized by the presence of pure $P$. sylvestris stands, with a density of approximately 300 plants/ha, and an average tree age of about 60 years. Each tree was visually inspected by eye or with binoculars when necessary. The infestation index was recorded in all pine stands by counting the number of nests and the degree of defoliation, according to six classes: 0 , zero, no nest, no defoliation; 1 , very low $\leq 0.1$ nest per plant, $<10 \%$ defoliation; 2 , low $=$ scattered nests, $0.2-0.5$ nests per plant, $10-25 \%$ defoliation; 3 , medium $=0.6-2$ nests per plant, $26-50 \%$ defoliation; 4 , high $=3-5$ nests per plant, $51-75 \%$ defoliation; 5 , very high $\geq 5$ nests per plant, massive defoliation (>75\%).

\subsection{Application of Control Strategies}

The infestation index was used to evaluate tree damage and determine threshold values above which control strategies were applied to control PPM infestations. Treatments with Btk were applied in those plots with an infestation index $\geq 3$. Conversely, mating disruption was applied at sites characterized by a low PPM population density (infestation index $<2$ ).

Microbial applications were performed at 20 different sites ( 5 sites per year) over a 4-year period (2016-2019). Each of these sites was at least $1 \mathrm{~km}$ away from monitoring traps to avoid compromising male catches, with a preference for areas with pure P. sylvestris stands and avoiding areas where the pines were mixed with other species, such as L. decidua, other Pinus species, and broadleaved trees. At each site, a plot of 100 pine saplings (about 0.30 ha) was sprayed with a commercially available bioinsecticide product based on B. thuringiensis var. kurstaki (Btk) (Kristal 32 WG, HD-1 strain, Serbios s.r.l., Badia Polesine (RO), Italy) at the rate of 32,000 BIU ha ${ }^{-1}$, in the presence of L1 and L2 larvae. Bioinsecticide was sprayed from the ground, up to a height of about $20 \mathrm{~m}$, between mid-August and mid-September, at about $20^{\circ} \mathrm{C}$ (in the twilight hours) and in partly cloudy weather conditions, using atomizer equipment supplied by CFVDA and the phytosanitary service of the Aosta Valley. A control plot, with an area and number of trees comparable to the treated plots, was chosen in the surroundings of each treated area, but far enough away to avoid contamination by the bacterium (at least $1 \mathrm{~km}$ ). Treatments were not performed if wind speed exceeded $7 \mathrm{~km} \mathrm{~h}^{-1}$ and were repeated in the case of heavy rain. The effectiveness of the microbial treatment was assessed 10 days after treatment evaluating larval mortality. To calculate the percentage of larval mortality, the number of dead larvae was divided by the total number of dead and live larvae recorded on all the saplings for each site.

Four municipalities were chosen for mating disruption over a 2-year period (Saint Nicolas and Sarre in 2016; Arvier and Villeneuve in 2017). In total, 23 and 19 plots were chosen in 2016 and 2017, respectively (11 in Saint Nicolas, 12 in Sarre, 10 in Arvier, and 9 in Villeneuve). At each site, a 1-ha plot of about 300 pine saplings was chosen. Pheromone dispensers (only lures without the traps) containing the specific sex pheromone component (loading rate: $50 \mathrm{mg}$ per dispenser) were placed on branches of $P$. sylvestris stands at an average height of $2 \mathrm{~m}$ within tree canopies immediately before adult emergence. Ten and 12 dispensers/ha were used in 2016 and 2017, respectively. For each plot, 
a control plot with an area and number of trees comparable to the treated plot was chosen in the surrounding area, but far enough away to avoid the effects of pheromone dispersion (at least $2 \mathrm{~km}$ ). The effectiveness of the technique was assessed using pheromone traps. The same type of traps as those used for monitoring was placed to collect male adults in the treated and control plots (6 traps/ha; loading rate: $1 \mathrm{mg}$ per dispenser). The traps were placed in a regular pattern throughout each plot to ensure even coverage. All traps were installed immediately before adult emergence and inspected for adult males at weekly intervals until mid-September. Captured males were counted and removed from the traps. The effectiveness of the treatment was assessed during December by recording the mean number $( \pm S E M)$ of nests/tree in all the treated and control plots.

\subsection{Statistical Analysis}

All data were first tested for homogeneity of variance (Levene's test), and transformations (log transformation and arcsine square rooted) were employed to stabilize variances and normalize the data. A paired t-test was used to assess differences in larval mortality comparing treated and control plots. Furthermore, a paired $t$-test was used to assess differences in male catches comparing plots where mating disruption was applied and control plots. Statistical significance was set at $p<0.05$. All analyses were performed using SPSS version 22.0 (SPSS, Chicago, IL, USA).

\section{Results}

A network of permanent plots intended for monitoring of the PPM was set up during the survey period. In total, 277 georeferenced traps were placed in the same position in each of the five years, except for 2015, when the number of traps was 135 (Figure 1).

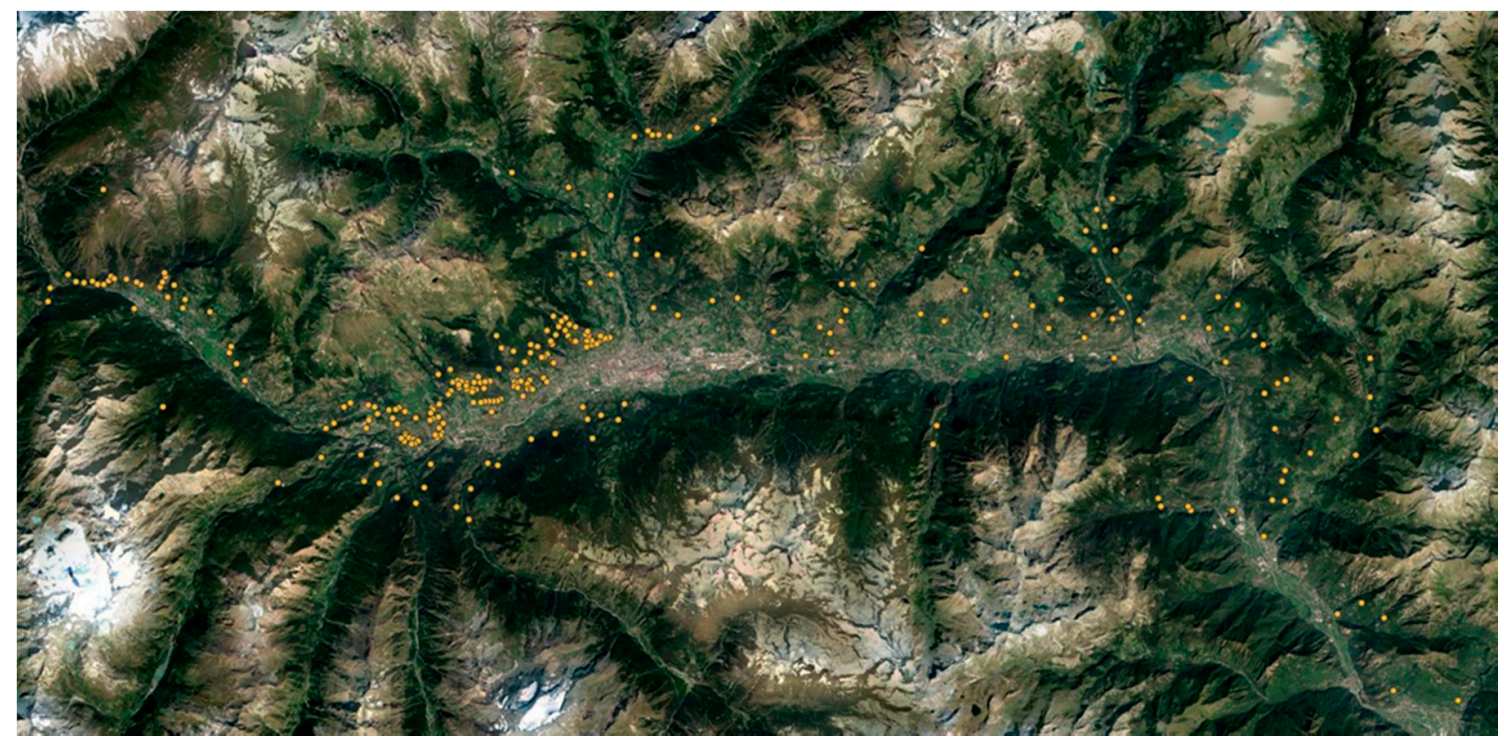

Figure 1. Map of the surveyed area in the Aosta Valley (north-western Italian Alps), showing the georeferenced pheromone baited traps placed in 2015-2019).

The total number of PPM adult males captured with funnel traps was 86,790, 150,652, 157,300, 152,118, and 61,612, in 2015, 2016, 2017, 2018 and 2019, respectively. The mean catches per week per trap ranged from 1.91 in Brusson in 2017 to 138.05 in Morgex in 2016. All data referring to the mean number of adult male PPM captured per week per trap and the total catch per week at all the surveyed sites are presented in Supplementary Materials Table S2.

In all years, the seasonal flight activity started at the beginning of June with the peak of adults on 3rd July (2015, 2016), 10th July (2017), 26th June (2018), and 17th July (2019). Males were found in traps until mid-September (Figure 2). 


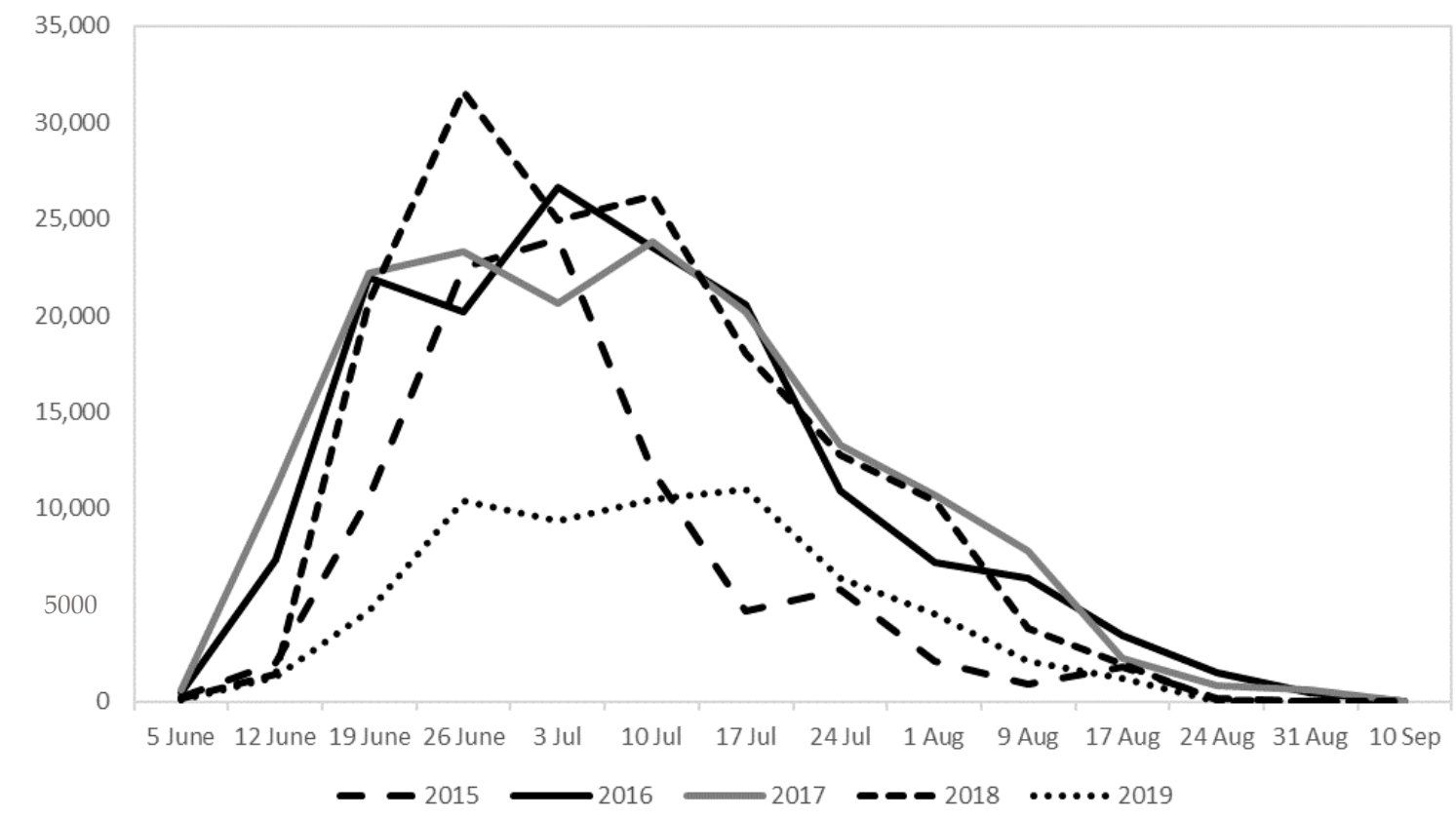

Figure 2. Total number of adults male of Thaumetopoea pityocampa collected with the pheromone-baited traps in the five-year period. (Data collected always refers to 277 traps, except for 2015 when the traps were 135).

In total, 9618 ha were visually monitored and assigned an infestation index. The percentage of woodland stands strongly defoliated by PPM (infestation index $\geq 3$ ) increased progressively between 2015 and 2016, increasing from 8\% to 19\% of the total area monitored. In spring 2016, "very high" defoliation (76-100\% loss of leaves) affected an area of 45 hectares, corresponding to $1 \%$ of the infested pine forests, while defoliation was "high" (with leaf loss between 51 and 75\%) in 10\% of the pine forests. The infestation index subsequently decreased to $16 \%$ and $13 \%$ in 2017 and 2018, and then suffered an abrupt decline to $4 \%$ in 2019 (Table 1). The most serious damage occurred in the municipalities of Morgex, Sarre, and Saint-Pierre.

In total, 367, 333, 208, and 253 ha were treated in 2016-2019, respectively. Btk treatments involved about $312 \mathrm{~km}$ of roads, covering a total area of about 1116 hectares of pine forests.

The mortality rate in the plots treated with $B$. thuringiensis was significantly higher than that recorded in the control plots. Where the bacterium was applied, the rate of larval mortality ranged from $79.47 \%$ to $98.43 \%$, with an average of $90.47 \%$. Conversely, in the control plots, the larval mortality ranged from $0.34 \%$ to $2.18 \%$, with an average of $1.56 \%$ (Figure 3 ).

Mating disruption was performed in 23 and 19 ha in 2016 and 2017, respectively. The mean number $( \pm$ SEM) of PPM male adults collected per trap and per week is given in Figure 4 . The mean number of PPM males was significantly lower in the plots where MD was performed, ranging from $8.36 \pm 2.37$ to $13.47 \pm 4.68$. Conversely, the mean number of males captured in the control plots was, on average, $119.16 \pm 12.68$.

The total number of nests recorded per tree was significantly lower in MD plots, ranging from $0.41 \pm 0.05$ to $0.94 \pm 0.14$. In the control plots, there was an average of $4.37 \pm 0.76$ nests per tree. 
Table 1. Infestation index recorded, and the total area (ha) treated with Bacillus thuringiensis var. kurstaki, and mating disruption in $2014-2019$.

\begin{tabular}{|c|c|c|c|c|c|c|c|c|c|c|c|c|c|}
\hline & & \multicolumn{2}{|l|}{2014} & \multicolumn{2}{|l|}{2015} & \multicolumn{2}{|l|}{2016} & \multicolumn{2}{|l|}{2017} & \multicolumn{2}{|l|}{2018} & \multicolumn{2}{|l|}{2019} \\
\hline & & No. Municipality & ha & No. Municipality & ha & No. Municipality & ha & No. Municipality & ha & No. Municipality & ha & No. Municipality & ha \\
\hline & & 42 & & 42 & & 42 & & 42 & & 42 & & 42 & \\
\hline \multirow{6}{*}{ 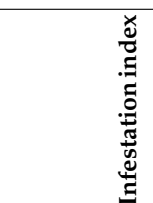 } & 0 & & 7598 & & 7310 & & 5482 & & 4809 & & 4713 & & 4520 \\
\hline & 1 & & 1058 & & 1154 & & 1539 & & 2597 & & 2212 & & 4040 \\
\hline & 2 & & 481 & & 385 & & 769 & & 673 & & 866 & & 673 \\
\hline & 3 & & 385 & & 481 & & 866 & & 673 & & 614 & & 289 \\
\hline & 4 & & 96 & & 192 & & 673 & & 577 & & 439 & & 96 \\
\hline & 5 & & 0 & & 96 & & 289 & & 289 & & 197 & & 0 \\
\hline \multicolumn{2}{|c|}{ Total treated (ha) } & & - & & - & & 367 & & 333 & & 208 & & 253 \\
\hline \multicolumn{2}{|c|}{ Bacillus thuringiensis var. kustaki } & - & - & - & - & 14 & 344 & 9 & 314 & 12 & 208 & & 250 \\
\hline \multicolumn{2}{|c|}{ Mating disruption } & - & - & - & - & 2 & 23 & 2 & 19 & - & - & & - \\
\hline
\end{tabular}



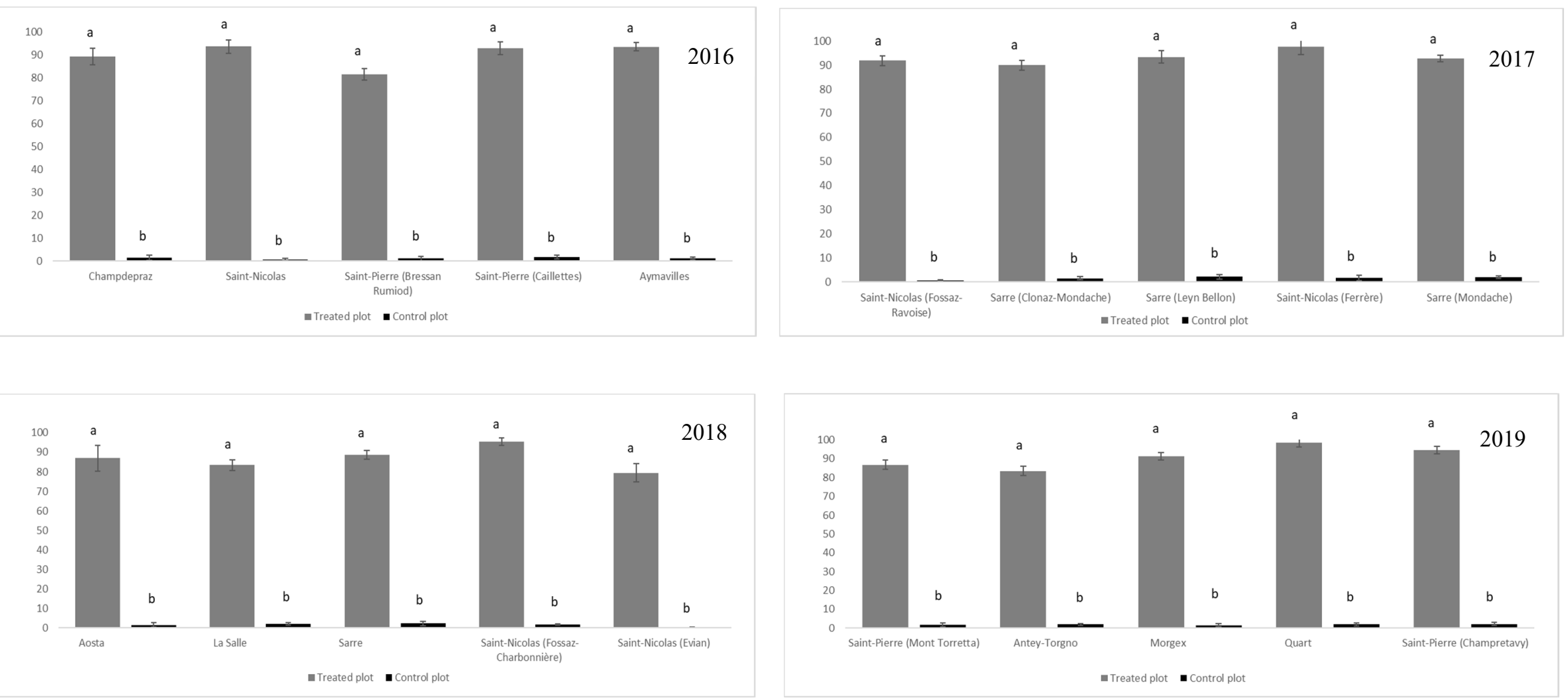

Figure 3. Percentage mortality of PPM larvae $( \pm$ SEM) recorded inside the nests collected in treated and control plots after applications of Bacillus thuringiensis var. kurstaki in 2016-2019. Bars with different letters are significantly different, according to the paired $t$-test $(p<0.05)$. 

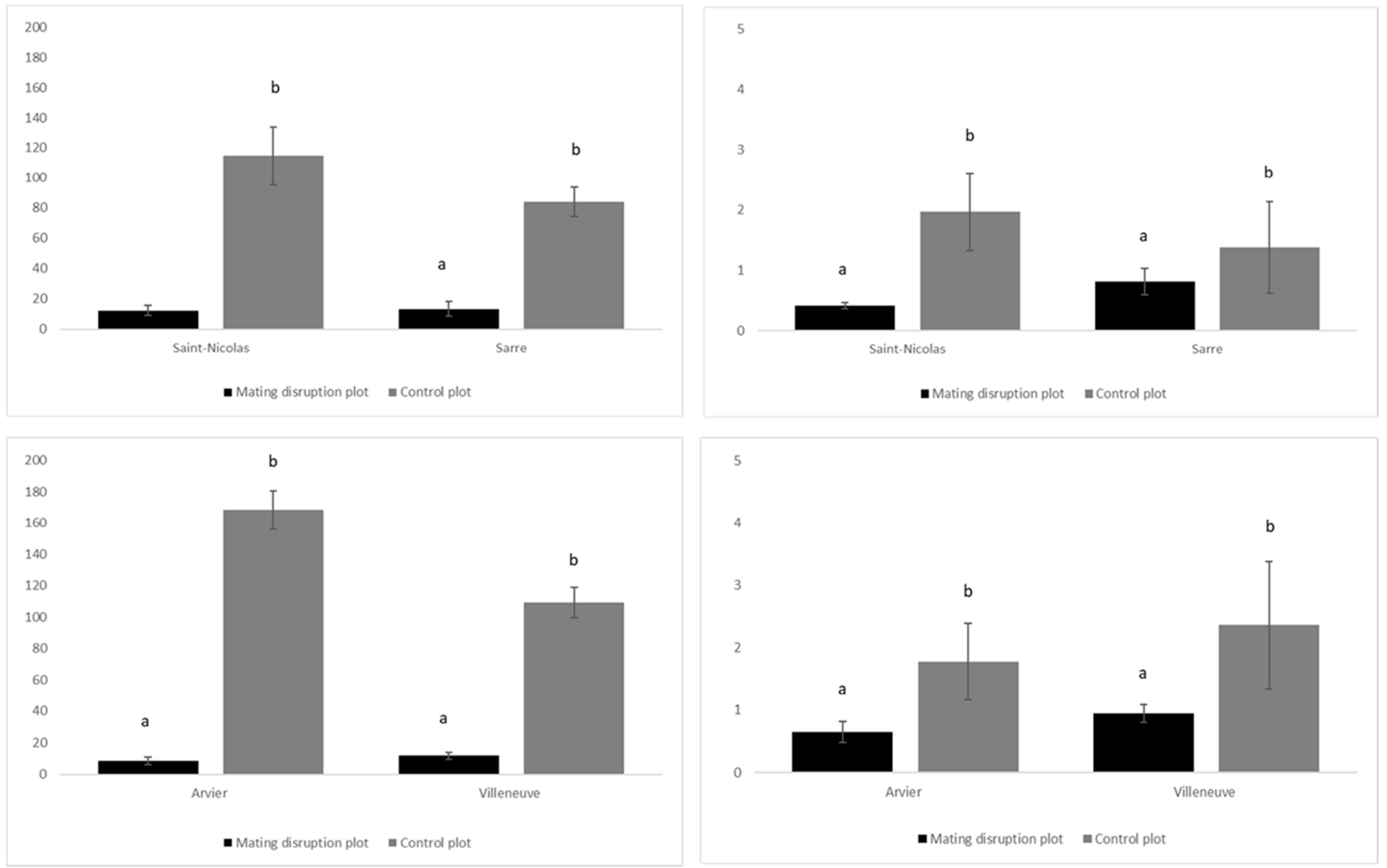

Figure 4. Mean number $( \pm$ SEM) of male adults/per trap/per week of Thaumetopoea pityocampa collected with pheromone-baited traps, and mean number $( \pm$ SEM) of nests/tree recorded in plots where mating disruption (MD) was applied compared to control plots in 2016 (top) and 2017 (bottom). Bars with different letters are significantly different, according to the paired $t$-test $(p<0.05)$. 


\section{Discussion}

Although T. pityocampa is a key pest of pine trees in the Alps, there is little information about its phenology and seasonal occurrence in the north-western Italian Alps. In the Aosta Valley, PPM infestation has been consistently investigated in forest monitoring programmes from the 1960s onwards, but the defoliator moth has only been intensively studied since the 2000s. The Aosta Valley pine forests mainly consist of black pine and Scots pine; defoliation damage ranging from mild to very severe, due to PPM feeding activity, has been observed in about 50\% of this area over the years (IR and LD). In 2016, the Department of Agriculture and Natural Resources, therefore, activated a plan to control PPM outbreaks.

Generally, mixed forests are less sensitive to pests and disease than pure stands. Although olfactory cues are commonly used to locate host trees, visual cues may affect the degree of infestation as well. Even in the case of PPM, mixed pine stands have been found to suffer less damage than pure pine stands [21], as non-host trees may act as physical barriers [22,23]. However, over the last century, several species of the genus Pinus have been widely used for afforestation [24], and this has clearly facilitated the spread of the PPM in the surveyed area. P. nigra is considered the primary native host of PPM, and the planting of this species has almost certainly promoted PPM population growth and outbreaks. Furthermore, PPM is reported to be sensitive to the severity and duration of the cold winter period, since it overwinters at the larval stage. The lethal temperature threshold is between approximately $-10{ }^{\circ} \mathrm{C}$ and $-16{ }^{\circ} \mathrm{C}$ [3], and the mean temperature increase over the last few decades has, thus, favored a higher survival rate from year to year, as already reported by Robinet [25]. In Aosta Valley, Mont Avic was used as a study site to monitor the expansion of PPM in the Italian Alps, where both an elevation gain $(113.7 \pm 23.0 \mathrm{~m})$ and distance gain $(232.7 \pm 22.4 \mathrm{~m})$ were observed in 2003 [26] .

In our survey area, the network of permanent plots established in 2015 revealed that the PPM population progressively increased to reach its highest values in 2017, and then decreased rapidly afterward. The seasonal flight activity started at the beginning of June and continued until mid-September. The trapping of male adults in pheromone-baited traps peaked between the end of June and the beginning of July, with a similar trend in each year that was consistent with the literature [27,28]. Reliable population density data from monitoring and assessment surveys are required for effective suppression of PPM infestations. Although the absolute number of catches per trap may not be entirely representative of the population, being strongly influenced by sex ratio and trap frequency and position [24], monitoring traps may be useful to identify low- or high-density population areas where physical removal of the nests, insecticides, microbial treatments and/or mating disruption can be applied. Since several control methods are available, a practical evaluation of their effectiveness is essential for decision making in current PPM control protocols.

The Aosta Valley is a renowned tourist area, and in the past decades, there has been an increasing need for effective pest management programs, with traditional control methods (e.g., intensive pruning or chemical pesticides) strongly discouraged. The most common environmentally friendly control strategies (e.g., mechanical, biological) have now been adopted in the forestry environment.

Microbial insecticides offer a great deal of promise for pest management, being effective in controlling several defoliating forestry insect pests (e.g., spruce budworm, gypsy moth), without posing the serious environmental hazards associated with conventional pesticides [29,30]. Several microbial antagonists (e.g., bacteria, fungi, and viruses) have been reported for the control of PPM infestations [16], but the only large database based on scientific investigations concerns the use of Bacillus-based preparations. Applications of commercially available bioinsecticide products based on Btk have increased in the last few decades, targeting PPM [16,31,32], and other forest-defoliating lepidopterans [33-35]. At the surveyed sites, different control strategies were applied with the aim of containing and mitigating PPM outbreaks. Btk applications and mating disruption showed promising results in terms of effectiveness in controlling the infestations. Where Btk treatment was performed, the PPM mortality was very high. The average larval mortality was $90.47 \%$ in the treated plots versus $1.56 \%$ in the control plots. Similar values, with PPM larval mortality rates up to $90 \%$, have previously 
been reported for Btk ground application in EU and Mediterranean countries [16,32]. In the literature, the susceptibility of the larvae to $B t k$ was found to be directly proportional to the application dose, and some authors reported that a second Btk spray within 10-15 days of the first application might be useful [16]. In the current study, only one application was performed targeting L1-L2 larvae, using the dose of 32,000 BIU ha ${ }^{-1}$, and the average larval mortality rate proved very high at all the surveyed sites and in all years, making a second application unnecessary. Similar to Btk applications, the use of pheromones to disrupt the mating of PPM was effective at all the surveyed sites, suggesting that pheromone lures may effectively decrease male captures. The number of males in pheromone-baited traps was significantly lower in all MD plots (on average, 11.47 males/captured/week in all sites) in comparison with the control (on average, 119.16 at all sites) during 2016-2017. The number of nests per tree also confirmed the effectiveness of this technique, as also demonstrated by Trematerra [36]. The values recorded were significantly lower in all MD plots (on average, 0.7 nests/tree) compared to the control plots (on average, 1.87 nests/tree), highlighting the success of this technique. Although some constraints regarding the size of the plot have been reported for agricultural pests because of the risk of adult immigration [37], our investigations were performed in 1-ha plots, and the satisfactory results are consistent with those reported elsewhere [36].

PPM has a typical cyclical pattern, where intermittent outbreaks are interspersed with periods of lower population densities. In the literature, peak defoliations are reported to occur every 6-11 years on average [38-40], while in the Italian Alps, no regular cycles have been detected [41] (although the different statistical methods applied may have influenced the final output). A negative gradation phase characterized by a decline in the PPM population commonly occurs when there is a significant reduction in food availability. In the current study, the PPM population experienced a clear decline in 2019 , but given that pine stands were not severely defoliated, it is more likely that this was due to the effectiveness of the set of control strategies applied rather than to the PPM's cyclical pattern. The pest is a strong public-health concern, due to the presence of urticating hairs that are present from the L3 larvae onwards, and which may affect humans, pets, and livestock in urban areas and forestry [13]. Btk applications and mating disruption have turned out to be the most appropriate control strategies for forest managers targeting the PPM. The adoption of such control strategies should be strongly encouraged by local authorities and administration policies, especially in areas frequented by people and in pine stands used for biomass production. Repeated annual applications of microbials and/or mating disruption could dramatically reduce population densities to levels below the economic injury level, with populations subsequently maintained at low levels with little management effort [42].

The role played by natural enemies is currently being investigated in Europe [40] and some Italian regions [42,43], and at least 18 parasitoid and 15 predator species have been recorded on the different stages of PPM. To date, the establishment of natural enemies in the Aosta Valley has not been studied, and little is known about their presence and potential impact along latitudinal or longitudinal gradients. Some questions remain to be addressed, and further studies should focus on the occurrence and adaptation of invertebrate natural enemies regarding PPM population dynamics. Since it is not completely clear how natural enemies respond to PPM outbreaks and what their role is in population regulation, specific research is needed to deepen our knowledge about the potential contribution and beneficial role of generalist parasitoids in controlling this defoliator moth in the surveyed area.

Further studies must also be performed regarding climatic conditions. Changes in diel activity and seasonal phenology patterns of both the PPM and oak processionary moth have been associated with global climate change [44], and moth emergence may be strongly affected by weather conditions, as already reported for the congeneric species T. wilkinsoni Tams [45]. All these further investigations, in addition to the data already recorded about seasonal occurrence and effectiveness of control strategies, will help provide a current global picture of PPM in the Aosta Valley, and allow for effective and sustainable management strategies to be adopted in the long term. 
Supplementary Materials: The following are available online at http://www.mdpi.com/1999-4907/11/12/1253/s1, Table S1: List of the monitored municipalities in Aosta Valley in 2015-2019, Table S2: Total number of male adults of Thaumetopoea pityocampa monitored with pheromone-baited traps in Aosta Valley in 2015-2019.

Author Contributions: Conceptualization, C.F., I.R., L.D.; methodology, I.R., L.D.; formal analysis, C.F., V.S., C.P., I.R.; data Curation, C.F., V.S., I.R.; writing-Original draft preparation, C.F., V.S.; writing—review \& editing, C.P., I.R., L.D., F.V.; project administration, L.D., F.V. All authors contributed to the writing of the manuscript and approved the final version. All authors have read and agreed to the published version of the manuscript.

Funding: This project was partially funded by the "MONGEFITOFOR" Project Interreg Cooperation Program Va ITA-CH 2014/2020.

Acknowledgments: The authors would like to thank all the forestry technicians of "Corpo Forestale della Valle d'Aosta" (CFVDA), and the phytosanitary service of the Aosta Valley for performing the field activity; Mario Negro, and Pierre-Yves Oddone for gathering data and assistance, and Raffaele Zanchini for the support in statistical analysis. The authors would like to thank the anonymous reviewers for their input in helping to improve the manuscript.

Conflicts of Interest: The authors declare no conflict of interest.

\section{References}

1. Chenchouni, H.; Zanati, K.; Rezougui, A.; Briki, A.; Arar, A. Population monitoring of Pine Processionary Moth (Thaumetopoea pityocampa) by pheromone trapping at the southern limit of distribution of Pinus halepensis in Eastern Algeria. For. Sci. Technol. 2010, 6, 67-79. [CrossRef]

2. Devkota, B.; Schmidt, G.H. Larval development of Thaumetopoea pityocampa (Den. \& Schiff.) (Lep. Thaumetopoeidae) from Greece as influenced by different host plants under laboratory conditions. J. Appl. Èntomol. 1990, 109, 321-330. [CrossRef]

3. Battisti, A.; Stastny, M.; Netherer, S.; Robinet, C.; Schopf, A.; Roques, A.; Larsson, S. Expansion of geographic range in the pine processionary moth caused by increased winter temperatures. Ecol. Appl. 2005, 15, 2084-2096. [CrossRef]

4. Buffo, E.; Battisti, A.; Stastny, M.; Larsson, S. Temperature as a predictor of survival of the pine processionary moth in the Italian Alps. Agric. For. Ėntomol. 2007, 9, 65-72. [CrossRef]

5. Arnaldo, P.S.; Torres, L.M. Effect of different hosts on Thaumetopoea pityocampa populations in northeast Portugal. Phytoparasitica 2006, 34, 523-530. [CrossRef]

6. Arnaldo, P.; Chacim, S.; Lopes, D.; Arnaldo, P.S. Effects of defoliation by the pine processionary moth Thaumetopoea pityocampa on biomass growth of young stands of Pinus pinaster in northern Portugal. iFor. BiogeoSci. For. 2010, 3, 159-162. [CrossRef]

7. Buxton, R.D. Forest management and the Pine Processionary Moth. Outlook Agric. 1983, 12, 34-39. [CrossRef]

8. Çatal, Y. The effects of pine processionary moth (PPM) defoliation degree on radial growth of brutian pine (Pinus brutia). Afr. J. Agric. Res. 2011, 6, 4931-4936. [CrossRef]

9. Gatto, P.; Zocca, A.; Battisti, A.; Barrento, M.J.; Branco, M.; Paiva, M.R. Economic assessment of managing processionary moth in pine forests: A case-study in Portugal. J. Environ. Manag. 2009, 90, 683-691. [CrossRef]

10. Kanat, M.; Alma, M.H.; Sivrikaya, F. Effect of defoliation by Thaumetopoea pityocampa (Den. \& Schiff.) (Lepidoptera: Thaumetopoeidae) on annual diameter increment of Pinus brutia Ten. in Turkey. Ann. For. Sci. 2005, 62, 91-94. [CrossRef]

11. Morr, I. Diagnostic protocols for regulated pests. Protocoles de diagnostic pour les organismes réglementés. EPPO Bull. 2004, 34, 271-279.

12. Colacci, M.; Kavallieratos, N.G.; Athanassiou, C.G.; Boukouvala, M.C.; Rumbos, C.I.; Kontodimas, D.C.; Pardo, D.; Sancho, J.; Benavent-Fernández, E.; Gálvez-Settier, S.; et al. Management of the Pine Processionary Moth, Thaumetopoea pityocampa (Lepidoptera: Thaumetopoeidae), in urban and suburban areas: Trials with trunk barrier and adhesive barrier trap devices. J. Econ. Ėntomol. 2017, 111, 227-238. [CrossRef] [PubMed]

13. Rossi, J.-P.; Imbault, V.; Lamant, T.; Rousselet, J. A citywide survey of the pine processionary moth Thaumetopoea pityocampa spatial distribution in Orléans (France). Urban For. Urban Green. 2016, 20, 71-80. [CrossRef]

14. Vega, J.M.; García-Ortiz, J.C.; Palla, P.S.; Sanchís, M.E.; Vega, J.; González-Muñoz, M.; Moneo, I.; Battisti, A.; Roques, A. Prevalence of cutaneous reactions to the pine processionary moth (Thaumetopoea pityocampa) in an adult population. Contact Dermat. 2011, 64, 220-228. [CrossRef] 
15. Cayuela, L.; Hódar, J.A.; Zamora, R. Is insecticide spraying a viable and cost-efficient management practice to control pine processionary moth in Mediterranean woodlands? For. Ecol. Manag. 2011, 261, 1732-1737. [CrossRef]

16. Battisti, A.; Longo, S.; Tiberi, R.; Triggiani, O. Results and perspectives in the use of Bacillus thuringiensis Berl. var. kurstaki and other pathogens against Thaumetopoea pityocampa (Den. et Schiff.) in Italy (Lep., Thaumetopoeidae). Anz. Schadl. 1998, 71, 72-76.

17. Shevelev, A.B.; Battisti, A.; Volynskaya, A.M.; Inovikova, S.; Kostina, L.A.; Zalunin, I. Susceptibility of the pine processionary caterpillar Thaumetopoea pityocampa (Lepidoptera: Thaumetopoeidae) toward delta-endotoxins of Bacillus thuringiensis under laboratory conditions. Ann. Appl. Biol. 2001, 138, 255-261. [CrossRef]

18. Parlak, S.; Özçankaya, I.M.; Batur, M.; Akkaş, M.E.; Boza, Z.; Toprak, Ö. Efficiency of funnel traps in controlling pine processionary moth. J. Plant Dis. Prot. 2018, 125, 539-548. [CrossRef]

19. Guerrero, A.; Camps, F.; Coll, J.; Riba, M.; Einhorn, J.; Descoins, C.; Lallemand, J. Identification of a potential sex pheromone of the processionary moth, Thaumetopea pityocampa (Lepidoptera, Notodontidae). Tetrahedron Lett. 1981, 22, 2013-2016. [CrossRef]

20. Bonsignore, C.P.; Manti, F. Influence of habitat and climate on the capture of male pine processionary moths. Bull. Insectology 2013, 66, 27-34.

21. Geri, C. Repartition et evolution des populations de la processionnaire du pin, Thaumetopoea pityocampa Schiff (Lep, Thaumetopoeidae) dans les montagnes. Acta Oecologica Oecologia 1983, 5, 3-22.

22. Jactel, H.; Birgersson, G.; Andersson, S.; Schlyter, F. Non-host volatiles mediate associational resistance to the pine processionary moth. Oecologia 2011, 166, 703-711. [CrossRef] [PubMed]

23. Demolin, G. Comportement des adultes de Thaumetopoea pityocampa Schiff. Dispersion spatiale, importance écologique. Ann. Sci. For. 1969, 26, 81-102. [CrossRef]

24. Masutti, L.; Battisti, A. Thaumetopoea pityocampa (Den. \& Schiff.) in Italy Bionomics and perspectives of integrated control. J. Appl. Èntomol. 1990, 110, 229-234. [CrossRef]

25. Robinet, C.; Rousselet, J.; Pineau, P.; Miard, F.; Roques, A. Are heat waves susceptible to mitigate the expansion of a species progressing with global warming? Ecol. Evol. 2013, 3, 2947-2957. [CrossRef]

26. Battisti, A.; Stastny, M.; Buffo, E.; Larsson, S. A rapid altitudinal range expansion in the pine processionary moth produced by the 2003 climatic anomaly. Glob. Chang. Biol. 2006, 12, 662-671. [CrossRef]

27. Mirchev, P.; Georgiev, G.; Geshev, G. Dispersal of male butterflies of pine processionary moth (Thaumetopoea pityocampa). Silva Balc. 2013, 14, 102-108.

28. Peter, B.; Manti, F.; Castiglione, E.; Battisti, A. Pupal traits and adult emergence in the pine processionary moth Thaumetopoea pityocampa (Lepidoptera: Notodontidae) are affected by pupal density. Eur. J. Ėntomol. 2019, 116, 320-329. [CrossRef]

29. Van Frankenhuyzen, K. Development and current status of Bacillus thuringiensis for control of defoliating forest insects. For. Chron. 1990, 66, 498-507. [CrossRef]

30. Cunningham, J.C.; van Frankenhuyzen, K. Microbial insecticides in forestry. For. Chron. 1991, 67, 473-480. [CrossRef]

31. Avtzis, N.D. The use of Bacillus thuringiensis against Thaumetopoea pityocampa Schiff. (Lepidoptera: Thaumetopoeidae) in Greece. In Proceedings of the Population Dynamics, Impacts and Integrated Management of Forest Defoliating Insects, USDA Forest Service, General Technical Report NE-247, Banská Štiavnica, Slovakia, 18-23 August 1998; pp. 311-316.

32. Cebeci, H.; Öymen, R.; Acer, S. Control of pine processionary moth, Thaumetopoea pityocampa with Bacillus thuringiensis in Antalya, Turkey. J. Environ. Biol. 2010, 31, 357-361.

33. Dubois, N.R.; Reardon, R.C.; Kolodny-Hirsch, D.M. Field efficacy of the NRD-12 Strain of Bacillus thuringiensis against gypsy moth (Lepidoptera: Lymantriidae). J. Econ. Èntomol. 1988, 81, 1672-1677. [CrossRef]

34. Roversi, P.F. Aerial Spraying of Bacillus thuringiensis var. kurstaki for the control of Thaumetopoea processionea in Turkey oak woods. Phytoparasitica 2008, 36, 175-186. [CrossRef]

35. Hajek, A.; Van Frankenhuyzen, K. Use of Entomopathogens against forest pests. In Microbial Control of Insect and Mite Pests; Elsevier BV: Amsterdam, The Netherlands, 2017; Volume 21, pp. 313-330.

36. Trematerra, P.; Colacci, M.; Athanassiou, C.G.; Kavallieratos, N.G.; Rumbos, C.; Boukouvala, M.C.; Nikolaidou, A.J.; Kontodimas, D.C.; Benavent-Fernández, E.; Gálvez-Settier, S. Evaluation of Mating disruption for the control of Thaumetopoea pityocampa (Lepidoptera: Thaumetopoeidae) in suburban recreational areas in Italy and Greece. J. Econ. Èntomol. 2019, 112, 2229-2235. [CrossRef] 
37. Carde, R.T.; Minks, A.K. Control of moth pests by mating disruption: Successes and constraints. Annu. Rev. Ėntomol. 1995, 40, 559-585. [CrossRef]

38. Robinet, C.; Baier, P.; Pennerstorfer, J.; Schopf, A.; Roques, A. Modelling the effects of climate change on the potential feeding activity of Thaumetopoea pityocampa (Den. \& Schiff.) (Lep. Notodontidae) in France. Glob. Ecol. Biogeogr. 2007, 16, 460-471. [CrossRef]

39. Geri, C.; Miller, C.; Xeuxet, D. Mesure des populations de processionnaire du pin (Thaumetopoea pityocampa Schiff-Lepidoptere Thaumetopoeidae) au Mont-Ventoux. Ann. Sci. For. 1985, 42, 143-184. [CrossRef]

40. Li, S.; Daudin, J.-J.; Piou, D.; Robinet, C.; Jactel, H. Periodicity and synchrony of pine processionary moth outbreaks in France. For. Ecol. Manag. 2015, 354, 309-317. [CrossRef]

41. Tamburini, G.; Marini, L.; Hellrigl, K.G.; Salvadori, C.; Battisti, A. Effects of climate and density-dependent factors on population dynamics of the pine processionary moth in the Southern Alps. Clim. Chang. 2013, 121, 701-712. [CrossRef]

42. Bonsignore, C.; Manti, F.; Castiglione, E. Interactions between pupae of the pine processionary moth (Thaumetopoea pityocampa) and parasitoids in a Pinus forest. Bull. Ėntomol. Res. 2015, 105, 621-628. [CrossRef]

43. Tarasco, E.; Triggiani, O.; Zamoum, M.; Oreste, M. Natural enemies emerged from Thaumetopoea pityocampa (Denis \& Sciffermüller) (Lepidoptera Notodontidae) pupae in Southern Italy. Redia 2015, 98, 103-108.

44. De Boer, J.G.; Harvey, J.A. Range-Expansion in processionary moths and biological control. Insects 2020, 11, 267. [CrossRef] [PubMed]

45. Houri, A.; Doughan, D. Behaviour Patterns of the Pine Processionary Moth (Thaumetopoea wilkinsoni Tams; Lepidoptera: Thaumetopoeidae). Am. J. Agric. Biol. Sci. 2006, 1, 1-5. [CrossRef]

Publisher's Note: MDPI stays neutral with regard to jurisdictional claims in published maps and institutional affiliations. 